\title{
Onufrego Kopczyńskiego mariaż gramatyki z polityką
}

Jacek Wójcicki 


\section{Jacek Wójcicki}

\section{Onufrego Kopczyńskiego mariaż gramatyki z polityką}

$\mathrm{P}$ rzydatność wielojęzycznych poradników konwersacyjnych zarówno dla ich bezpośrednich użytkowników, jak i dla badaczy, oglądających zjawiska kulturowe z rozmaitego oddalenia czasowego i przestrzemnego, jest w oczywisty sposób co najmniej dwojaka.

Pierwsza korzyść - można ją nazwać uzualną - to praktyczne poznanie świata gospodarzy w jego namacalnych, wielowymiarowych ksztaltach, w zakresic niezbędnym do znalezienia przez przybysza właściwej drogi wśród fenomenów dotąd nieznanych lub zaledwie ludząco podobnych do miejsc i sytuacji oswojonych. Jest to spojrzenie z punktu widzenia gościa, o charakterze, nazwijmy to, statyczno-topograficznym. Z kart „rozmów”, „skarbczyków”, „kluczy”, „drzwi” (lub jeszcze inaczej tytułowanych tomików) czytelnicy dowiadıją się, gdzie się znaleźli, co się tu zwykle dzieje, a także, co powinni zrobić, by osiągną̧́ ten cel, dla którego wędrówkę ku obcym krajobrazom i między nowych rozmówców w ogóle przedsiębrali — z własnej woli bądź posłusznni jakiejś wyższej nad nich sile.

Druga sfera poznawcza ukazuje przybyszowi nie tylko to, co w nowym dlań świecie z przyczyn utylitarnych robić warto, wypada lub trzeba, lecz także to, czego uczynić nie wolno, pod karą niekiedy urzędową, zapisaną w doknmentach sądowniczych, ale najczęściej wynikająca ze zwyczaju i niepisanego kodeksu honorowego danej społeczności (przez co nieraz dotkliwszą od sankcji oficjalnych). Teraz na cudzoziemskiego gościa zaniepokojonym wzrokiem spoglądają gospodarze - z obawą, ma się rozumić, już tylko metaforyczno-metafizyczną, gdy „gościem” książki po dziesięcioleciach czy wręcz wiekach jest badacz, lecz jakże zrozumiałą i prawdziwą, gdy terenem ryzykownego spotkania ma być czyjaś „mała ojczyzna” na Ziemi. Tę część nauki wyplywającej z poradników językowych wypada nazwać nomatywno-perswazyjną.

Rzecz jasna, rzadko kiedy ksiązeczki użytkowe, mające dopomóc rozmówić się w podróży studentom, żołnierzom, rzemieślnikom, handlarzom czy po prostı wojażerom, ogarniają 
cale bogactwo kulturowego uniwersum gospodarzy - a i różnice między nimi a gośćmi nie zawsze są bardzo głębokie. Przeważnie też powszechnie uznane wskazówki etyczne zawierają się jedynie implicite i fragmentarycznie w przykładowych rozmowach dotyczących handlu, konsumpcji, usług, spraw bytowych lub rozrywek. Dlatego przedstawiona powyżej typologia ma walor jedynie modelu, a jego jednostkowe realizacje w bardzo różny sposób obejmuja obie dziedziny poznania. Warto jednak spostrzec, że granica między nimi jest zazwyczaj nieostra, ponieważ w kontaktach międzykulturowych - może od razu należałoby uściślić: kontaktach pokojowych — korzyść utylitarna bywa jednak uwarunkowana przestrzeganiem wartości moralnych, a petne poznanie realiów wymaga orientacji w imponderabiliach. Przynajmiej w świetle użytkowych publikacji jawnych; wszak tam, gdzie skuteczność bierze rozbrat z moralnością, wskazówki dla różnej rangi oszustów - wyjąwszy może traktaty o podstępach wojennych, Księcia Machiavellego i zawierające ten motyw moralitety w rodzaju Kupca Mikolaja Reja — pozostają domeną konspiracyjnego przekazu mówionego.

Ciekawym przykładem przeplatania się wymienionych wcześniej wątków są wydane na początku lub w pierwszej polowie 1807 roku we Wrocławiu u Korna francusko-polsko-niemieckie rozmówki, wieńczące trójjęzyczny stownik Petit vocabulaire des vojageurs... pour servir à 'entretien de trois nations'. Przeznaczono je po pierwsze dla żohnierzy napoleonískich — w tym również niemieckojęzycznych, pochodzących z krajów Związku Reńskiego, świeżo utworzonego (w lipcu 1806 roku) pod egidą Francji, walczącej przeciw czwartej koalicji (Prus, Rosji i Anglii):

- (...) To jest izba Waćpana, dostaniesz jeszcze dwóch kamratów.

- Cóż to są za ludzie?

— Są to Wircburczyki, Bawarczyki, I Iassy, Prymasowscy² ${ }^{2}$, Wirtemberczyki itd.

(Rozmou'a zotnierza na marsu z gospodarzem, s. 107)

Po wtóre zaś - użytkownikami publikacji mieli być mieszkańcy tych terenów Królestwa Prus, przez które wiódł szlak ówczesnej Wielkiej Armii.

Podstawowym zadaniem rozmówek wydaje się praktyczne ukazanie kłopotliwych sytuacji, w których znaleźć się mogą i maszerujący żołnierze, i przymuszeni kwaterować ich mieszczanie (pierwsza z nich wlaściwie tworzy spójną jednoaktówkę, której „fabula” opowiada o nieporozumicniach na tym tle, ostatecznie przezwyciężonych przez obie strony sporu). Odmalowana przy tej okazji odmienność zwyczajów życia codziennego Francuzów od Niemców (w tym takze polskich obywateli Prus) miewa również niebagatelną wartość pozllawczą:

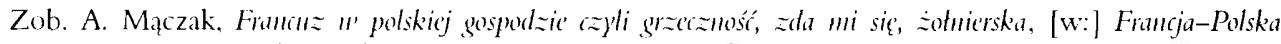

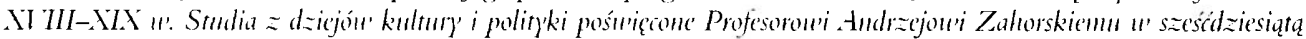
rocanice urodzin. Warszawa 1983. s. 105-111 (tekst polski, bez uwspólcześniania pisowni, przytoczony od s. 107: stạd dalsze cytaty - w pisowni zmodernizowanej — z lokalizacją w nawiasic); toż w skrócie (bez

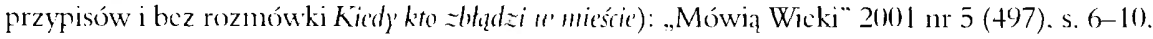

- Chudzi o zohnicrzy ksiçcia prymasa Związku Reńskicgo. przedtem arcybiskupa Moguncji. 
— Łóżko musi być po francusku posłane, to jest materac trzeba położyć na piernacie, a zamiast tej pierzyny proszę mi dać wehnianą albo przeszywaną kołdrę z prześcieradłem. Francuzi nie sypiają w pierzach (...) (s. 108).

Jednak, jak się wydaje, punkt ciężkości pada na kwestie moralne: przede wszystkim na zachowywanie przez wojsko w stosunku do lıdności cywilnej podczas działań militarnych norm etycznych z czasów pokoju. Autor publikacji zadbał o to, by racje obu stron rozłożone były równomiernie. Spokojny mieszczanin zmuszony jest udostępniać i sporym kosztem ogrzewać izby dla niezadowolonych żołnierzy oraz żywić ich, wprawdzie smacznie, lecz nie zawsze podlug gustu:

— Proszę, panie gospodarzu, daj mi zamiast piwnej zupy rosół albo polewkę z mléka; zaden Francuz nie lubi piwnej polewki, bo ta u nas nie jest woale w używaniu (s. 109).

Przecież nie on odpowiada za polityczny zamęt; sam też znosi uciążliwości trudnycl czasów. Dlatego obroną gospodarza — formalnie mieszkańca kraju nieprzyjacielskiego — przed gwałtami ze strony wojska (a w każdym razie pretensjami: „...nie pytam się o Waćpana wymówki, ja chcę mieć pieczenię, biały chlcb i wino" - s. 107) mają być dokumenty urzędowe: „cesarska zaloga” i ,regulament” (s. 108). Przydaje się też zimma krew i stanowczość:

— Ja wolę sam stać; daj mi Waćpan inszą izdebkę.

— Tego nie mogę uczynić; ta izba jest dla mnie i mojej familii. Góme piętro najęte, a więcej nie mam izb. (...)

— (...) Albo mi Waćpan daj osobną izdebkę, albo mi zapłać talara, a ja pójdę i wyrobię sobie inszy bilet.

- (...) Ci obydwa panowic ustąpią Waćpanu tego lóżka, które ja czysto oblokę. Chcesz Waćpan tym się kontentować, to dobrze, ale pieniędzy ja nie dam, i nie potrzebuję dawać, bo choć Waćpan pójdziesz, to ja dostanę inszego żołnierza (s. 107).

- Ten regulament służy tylko dla garnizonu, ale nie dla wojsk przechodzących, dla tych, co z marszów zmordowani.

— Pozwól Waćpan, ten regulament nie czyni żadnej różnicy, i owszem, stoi wyraźnie: „każdy żolnierz”. Do tego my się stosıjemy, i od tego ja nie odstąpię (s. 108).

— Kawa będzie o godzinie szóstej gotowa, ale co mięsa, tak rano Waćpanu dać nie mogę, bo go nie mam, i żona moja w nocy gotować nie może. Zamiast tego dam Waćpanu dobry kawał chleba z masłem i naleję Waćpanu w flaszeczkç wódki (s. 109).

Ale zdecydowanie gospodarza nie wyklucza wcale, przez przymusowego lokatora zauważanej w którejś chwili z akceptacją, indywidualnej jego „grzeczności” (s. 108). Bowiem woj- 
skowi dhugo maszerıją, bywają zmęczeni, chorzy i ranni (to temat rozmówki drugiej); im także należy się wspólczucie, a ich usprawiedliwieniem w oczach gospodarza winna być choć to akurat slowo w rozmówkach nie pada — „ludzkość”. W podtekście obecny pozostaje bowiem moralny sens wysiłków żołnierzy Napoleona: w dalszej perspektywie niosą oni przecież pożądany pokój, kiedy to wreszcie możliwe będzie prawdziwe spotkanie trzech narodów, wspomnianych w tytule rozmówek:

- Adien, szczęśliwej drogi życzę Waćpanu, a jeżeli Waćpan zdrów powrócisz z wojny i tędy przechodzić będziesz, to proszę mię odwiedzić i opowiedzieć mi, jak mu siç powodziło. Bądź Waćpan zdrów (s. 109).

Okazıje się jednak, że w tym samym okresie nadzwyczaj wzmożonych nadziei narodowych, wywolanych na jesieni 1806 roku proklamowaniem „wojny polskiej”, a wnet umocnionych - mimo wielı wątpliwości i zastrzeżeń - powołaniem do życia w lipcu 1807 roku, na mocy układı w Tylzy, Księstwa Warszawskiego, wydana została, na pozór tylko utylitarna, publikacja językowa, której niespodziewany a silny charakter perswazyjno-etyczny pozostawał dotąd nierozpoznany. Jest nią — jak głosi tytul — ,zarys praktycznej i rozumowanej gramatyki polskiej dla Francuzów”- opracowany przez najwybitniejszy ówczesny autorytet językoznawczy, na którego podręcznikach wychowywaly się już kolejne pokolenia - Onufrego Kopczyńskiego ${ }^{5}$.

Oczywiście, tych jego zasług szerzej roztrząsać nie trzeba. Ponieważ jednak o wiele mniej rozpowszechniona jest wiedza o dorobku Kopczyńskiego jako płodnego twórcy literatury okolicznościowej — dodajmy: w języku lacińskim (z jednym tylko wyjątkiem) — nie od rzeczy będzie przypomnieć jego dokonania na tym polu, by uzyskać szersze tło, na którym zostanie przedstawiona zawartość owej „perswazyjnej” gramatyki polskiej dla cudzoziemców, dzieła tyleż opisowego, co kreacyjnego.

Jeszcze przed dokonaniem jakichkolwiek obserwacji tekstowych można zauważyć, że powtarzającą się cechą formahną okolicznościowych wierszy Kopczyńskiego jest lączenie w jednym zestawie ,.obiektywnego” utworu głównego (zwykle stosującego retoryczny chwyt prozopopei - fikcyjnej wypowiedzi osoby, którą może być nie tylko człowiek, lecz także upersonifikowane zwierzę czy nawet kamienny posagg) oraz bardziej subiektywnego, krótszego dopowiedzenia pod adresem postaci realnej bądź wyobrażonej (jak na przykład złośliwego prze-

\footnotetext{
".Trudno opisać cntuzjazm Polaków" - strwicrdza wprost oficjalny 36. biulctyn Wiclkicj Armii, datowany z Poznania I grudnia 1 \&o6 roku. .... Najwaznicjszym uczucicm, jakic panıje, najwiçkszym pragnicnicm, to stać się znów narodem”: Polacy „Wlożyli już wszędzie na siebie swe dawne stroje i wracają do dawnych obyczajów" (cyt. zal: Napolcon Bonaparte, Mon'y' i rozkazy, tl. K. Znamicrowski, Warszawa 2002, s. 86).

+ Zob. O. Kopczyński, Essai de grammaire polonaise pratique et raisomáce pour le' Frangais, Varsovic 1808. Anectissement we francuskoj̧̨zyczncj prasic warszawskicj zapowiadal książkç już w maju roku poprzedniego — zob. ..Gazette de Varsovic" 1807 nr 53 (18 maja).

"Sylwetk ç uczonego pijara przedstawila kilkakrotnic lrena Stasicwicz-Jasiukowa - zob. eadem, Omufr' Kopcz'niski (1735-1817). [w:] Pisarze polskicgo ośl'icicunia, red. T. Kostkiewiczowa. Z. Goliński, t. 2, Warszawa 1994, s. 181-206: obszernicjsza monografia zob. cadem. Omufry Kopez)niski wspótpracoumik Komisji Ed dukacji Narodo-

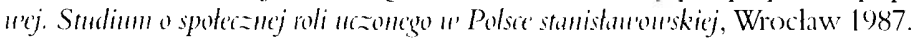


śmiewcy - bożka Momusa, nazwanego w polskiej wersji autorskiej swojskim imieniem „Gryzosława”).

Z roku 1776 pochodzi pierwsza tego typu znana nam publikacja - ulotny druk, zawierający cykl wierszy poświęcony zmarłej i pochowantj w Polsce córce ambasadora rosyjskiego Ottona Magnusa Stackelberga, która zresztą w ostatnim utworze sama przemawia do braci „z Pól Elizejskich". Żałobny trójglos poetycki akcentuje ludzki wymiar straty poniesionej przez ambasadora, a zarazem podkreśla więzi przyjacielskie i rodzimne, których kultywowanie, jak należy wnosić z wierszy, jest osobistąjego cnotą. W ten sposób poeta pijarski pozostaje w zgodzie z regulami zakonu, zakazującymi tworzenia pochlebczych panegiryków, a jednocześnie formuluje pośrednio pod adresem wszechwladnego dyplomaty taki komplement, który nie odnosi się do jego funkcji politycznych.

Adresatem drugiego utworu lacińskiego z tegoż roku - tym razem obszernego poematu - jest sama cesarzowa Rosji, nad której rzeźbą pracowal wówczas jeden z nadwornych snycerzy Stanisława Augusta, Giacomo Monaldi. Utwór, wprawdzie pełen mitologicznej erudycji i wieszczego zapału, i tym razem mieści się w ramach deconm, uwarunkowanego okolicznościami politycznymi. Równolegle z uczczeniem imienin Katarzyny II Kopczyński slawi bowiem artystę, a szerzej - geniusz człowieka, przy okazji głosząc zasługi króla jako mecenasa artystów i opiekuna wszelkich sztuk w rozkwitającym kraju.

Już po niecałych dwóch miesiącach Kopczyński wystapił z dwujęzycznym drukiem ulotnym ku chwale rocznicy urodzin Stanishawa Augusta (17 stycznia) ${ }^{\circ}$. Opatrzony licznymi przypisami utwór jest rozbudowanym konceptem heraldycznym, wykorzystıjącym skojarzenia herbu królewskicgo (Ciołek) i mitologicznej legendy o Jowiszu, pod postacią byka uprowadzającym księżniczkę Europę. Nowy „Ciolek” opowiada perypetiach swoich i Polski, cierpiącej zamęt (w domyśle: wojny domowej, interwencji sąsiedzkiej i rozbiorów), ostatecznie jednak dźwigającej się ku pomyślności, ponieważ bogini mądrości Pallas Atena raczy dalej zaszczycać wladcę swoją opieką.

\footnotetext{
"Zob. In amore dotor XII' Calendas Decombres. WDCCLXXI 7. |b. m. dr.) (1. Ad comitem de Stuckelberg Russortum

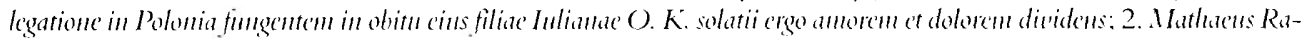

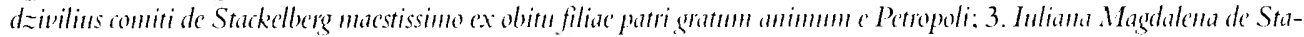
ckellocrg macrentibus stu morte fratribus ab Elysiis salutem). Korzystalem z unikatu Bibliotcki PAU-PAN w Krakowie (sygn. 119608). ze zbiorów Cypriana Walewskiego.

${ }^{7}$ Zob. Monmmentum Catharinae Secundae, [b. m. dr. (1. Die natali Catharinae Scommhe Russorum Caesaris in mar-

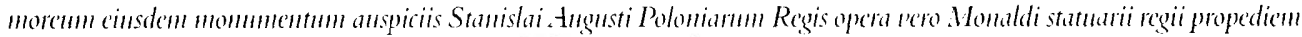

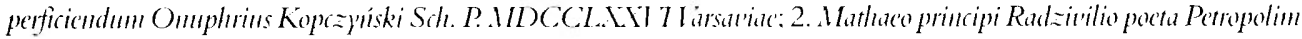
S. P.). - Monaldi czynny byl w Polsce od roku 1768, notabene monografista nic wymicnia wśród prac tego rzeźbiarza popicrsia Katarzyny II, znajdujacego siç do grudnia 1795 roku w zbiorach królewskich — zub.

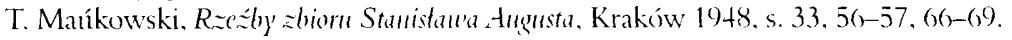

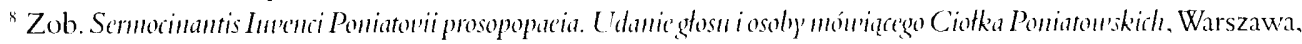
1. Dufour. 1777 (1. Sapientissimo elcmentissimoque regi smo poeta: 2. Dic Hatali Stanislai . Angusti Poloniarmm regis ser-

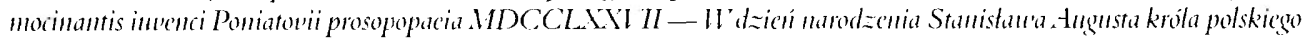

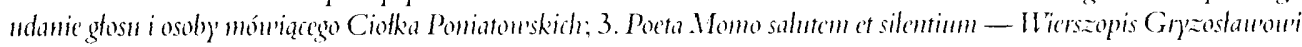
zdrontia i milczenia).
} 
Kilkuletnia przerwa w twórczości okazjonalnej spowodowana zostala intensywną pracą Kopczyńskiego nad gramatyką polską, którą w kolejnych tomach (trzy części przeznaczone dla uczniów, każda z towarzyszącymi Prz)'pisami - komentarzami metodycznymi dla nauczycieli, oraz syntetyczny Lktad gramatyki dla szkót narodou'ych i elementarna Nanka pisania iczytania) wydawal w latach 1778-1785. Skutkiem równolegle prowadzonej, wytężonej pracy nad tablicami stownikowymi języka polskiego była między innymi choroba oczu, której zaradził sławny warszawski okulista Walenty Gagatkiewicz, w roku 1783 obdarzony królewskim medalem Merentibus, a przy tej okazji uczczony przez pijara lacińską elegią". I tym razem w laudacji nie chodzi jedynie o partykularne zasługi lekarza czy też o chęć wywyższania własnej osoby piszącego, lecz o pochwalę umiejętności, pielęgnowanych wśród poddanych dzięki królewskiemu mecenatowi i systemowi nagród, tak by ludzie wyksztalceni i zdolni mogli stosować swoje talenty w praktyce, skutecznie przeciwstawiając się przeszkodom stawianym przez naturę przed rozwojem czlowieka jako indywiduum oraz ludzkości jako takiej.

W okolicznościach wrzenia politycznego epoki Sejmu Wielkiego Kopczyński opowiadal się po stronie patriotów, dążąc jednocześnie do propagowania i utrwalania, za pomocą dostępnych sobie środków wyrazu, koncepcji politycznej „Król z narodem, naród z królem”. Shużyły temu dwa różnych rozmiarów utwory. Pointą krótkiego, anegdotycznego opisu okoliczności wdziania przez króla podanej mu czapki szlacheckiej, gdy udawal się galerią z Zamku do katedry na nabożeństwo dziękczynne po uchwaleniu Konstytucji 3 Maja, jest odczytanie tego zdarzenia w sposób symboliczny, jako potrzeby jedności szlachty i monarchy, spojonych umiłowaniem wolności"1. Dłuższy poemat, znów - jak wcześniej prozopopeja herbowego Ciolka z roku 1777 - przeznaczony na styczniowe obchody królewskich urodzin, skierowany zostal w burzliwym roku 1792 ,przeciw Polakom-niedowiarkom”, wątpiącym w powodzenie ojczyzny".

Niebawem jednak wszelkie nadzieje gwaltownie przygasły, a Kopczyński - wyjątkowo aktywny, jak świadczą różne źródla wspólczesne, po stronie powstańczej w czasie insurekcji kościuszkowskiej - osobiście odczul ciężar klęski. Aresztowany przez Austriaków i w latach 1798-1802 więziony w klasztorach o zaostrzonym rygorze, dopiero w początkach XIX wieku.

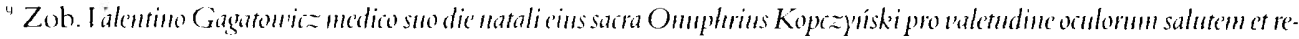
ginm numisma d. d., MI)CCLXXXIII, [b. m. dr.] (1. Elegia; 2. Ad cundem accepture mumisma remuentem epigramma) - Bibliografia polskia Estreichera (t. 20. Kraków 19015. s. 74) pod nazwiskicm Kopczyískiego notuje też nieza. chowany dziś druczek ze zbiorów Bibliotcki Krasińskich Iảentino Gagratkien'icz oculorum suorum medico di 14 Februarrii] 1792 (.,strotka po lacinic i po polsku ma ćwiartce”).

"Zob. Pilcus libertatis symbolon et palladimm quo usus c'st Stanislaus - Augustus Poloniarmm rex dum memorabili die $3 \mathrm{Ma}$

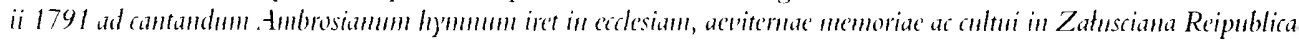

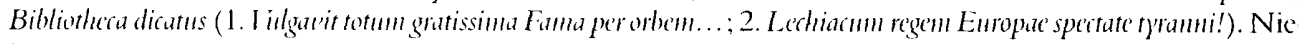
bawem ukazaly się drukiem trzy thumaczenia wspólczesnc na j̧̨zyk polski: Czapka zllak i puklerz uolności. Michaha Wyszkowskicgo. Czapka unolnośri skhad... Jana Szlubowskiego (unikat - druk w rpsic Biblioteki Czar toryskich w Krakowic, sygn. 938) oraz Czapka cecha i zatoga u’olności... Józefa Epifaniego Minasowicza (z kilko ma whasnymi dodatkami thmacza).

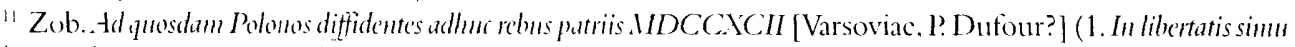
Lacrum die 17 Ianmarii: 2. All quosidam diffidentes). 
uwolniony dzięki staraniom Adama Jerzego Czartoryskiego, mógł wrócić do pracy zgodnej ze swoim powolaniem. Wtedy to nawet wybrany został na stanowisko prowincjała zakonu (w latach 1804-1807). Inaugurację swego urzędowania, juz jako poddany króla pruskiego, zaznaczył między innymi kolejnym lacińskim utworem okolicznościowym - w formie wierszowanej zachęty pod adresem wspólbraci zakonnych, i w ogóle duchowieństwa, do wytrwatej pracy w zmienionych warunkach politycznych ${ }^{12}$.

W tym miejscu można przerwać przegląd chronologiczny dla dokonania paru spostrzeżeń ogólnych. W okolicznościowej poezji Kopczyńskiego da się mianowicie wyróżnić kilka zmiennych z upływem czasu kręgów tematycznych, zawsze jednak, jak się wydaje, dostrzegalna jest spajająca je zasada, którą trafinie określiłoby, nieco paradoksalne, miano „powstrzymywanego maksymalizmu". Za każdym razem w centrum politycznego ukladu odniesienia dla owych utworów znajduje się jakaś znacząca postać, uosabiająca stabilność (najczęściej tylko pozorną i pożądaną) kolejnego odcinka dziejów, ale też za każdym razem poeta, sięgając jak najdalej ku granicom panegiryzınu, stara się tych granic nie przekroczyć. Sluży temu przede wszystkim sam wybór języka. Łacińska szata poezji uczonej, obwarowanej przepisami poetyki i retoryki, oddala osobę, „wieszcza” na bezpieczny dystans od rzeczywistości, pozwalając oddzielić realna jednostkę od spełnianej przez nią funkcji "głosu publicznego". W szczególności pomocna jest tu wspomniana już zasada prozopopei, ożywiająca figurę zastępczą, na której konto zapisać można cwentualną niepożądaną przesadę. Pijarski poeta stroni też od kierowania swoich słów bezpośrednio ku każdorazowej postaci centralnej, wybierając na adresatów raczej pośredników: dyplomatów, parlamentarzystów, artystów.

Nie trzeba chyba dodawać, że tak pojmowana poezja okolicznościowa nie ma charakteru twórczości subiektywnej, lecz podyktowana jest obiektywnymi, nadrzędnymi racjami zbiorowości. Kopczyński jest tu kontynuatorem drogi twórczej wielkiego poprzednika, Stanisława Konarskiego, który w poezji lacińskiej ${ }^{1.3}$ poruszał tematy istotne z dwóch głównych punktów widzenia: moralności indywidualnej (wychowanków edıkowanych w Collegium Nobilitum i innych szkołach, gdzie wiersze reformatora pijarów mogły być czytane i komentowane) oraz - wyrastającej z poprzedniej - morahności zbiorowej, ważnej ze względu na obywatelski ideal publicznej sluzby dla dobra Rzeczypospolitej.

Zewnętrzne okoliczności sprawily, że na pierwszym etapie okolicznościowej twórczości poetyckiej Kopczyńskiego-regalisty (i realisty) jako niewzruszone centrum politycznej koniunktury europejskiej jawila się Katarzyna II, nosobienie stabilizacji w Polsce epoki Rady Nieustającej ${ }^{1+}$ (czyli czasu ,rządów ambasadorskich”, stąd zapewne także uwaga poety zwrócona na postać Stackelberga). Tu wystowienie i koncepty poety budzić mogą najwięcej wątpli-

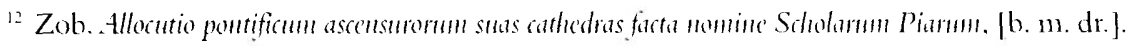

13 W przeważającej wiçkszości zgrupowancj w zbiorach Opera lyrica (Varsoviac 1767) i Carmina prosthuma (Varsoviac 1778).

${ }^{14}$ W przypisie do dedykacji królowi wiersza Sermocimantis In'enti Poniatorii prosopopaéia autor wylicza trzy poprzednic poczje okolicznościowe, w tym dwa teksty znanc obecnic (In obitum Inlianac contitis de Stackellberg; Momumentum Catharinac Seandac). Utwór wymieniony pod tytulem Rada Vienstająa pozostaje dziś nicznany.
} 
wości, czy istotnie Kopczyński nie przekroczyl owych granic panegirycznego „mniejszego zła”, dopuszczalnego z przyczyn politycznych. W wierszu do Stackelberga (cz. II, w. 5-10) Maciej Radziwilt pisze z Petersburga, ze zmarła Julianna Magdalena jest w podobnym do niego samego, a nawet lepszym odeń położeniu: jego (Radziwilla) los jest wciąż niepewny, podczas gdy Magdalena, jak jej ewangeliczna imienniczka, osiągnęla już spokój u boku Chrystusa — przede wszystkim zaś Radziwill ogląda stale tylko „ziemską boginię” (Katarzynę!), a Stackelbergówna samego Boga... Na usprawiedliwienie tego skrajnego ześlizgu pióra dodać należy, iż w części III autor każe zmarkej córce ambasadora podkreślać fakt, że pogrzebana została w gościnnej polskiej ziemi nie jako „wygnanka”, a cała jej przemowa zza grobu kończy się apelem do Polaków o kultywowanie cnót przodków.

Poemat poświęcony marmurowemu posągowi cesarzowej pozostaje również w nastroju entuzjazmu, lecz - jak wspomniano - thumaczyć go może zarówno poetyka wzniosłości, jak i konwencjonalny w sumie charakter pochwal „Semiramidy Północy”. Jako gorzką pointę dodać można, że Kopczyński, przesylający Maciejowi Radziwiłłowi wyrazy zazdrości z powodu stałego przebywania adresata u boku wielkiej władczyni, znajduje się w tym okresie swojej twórczości okolicznościowej w całkiem dobranym gronie - Diderota i Woltera...

Drugi etap poezji okolicznościowej Kopczyńskiego oznacza twórczość pod znakiem króla Stanisława Augusta. Ideowo można odczytywać to przesunięcie akcentów jako chęć propagandowego wzmocnienia wiary narodı we własne siły. Widać, że w zakresie wysłowienia autor posługuje się nadal rozbudowanym i barwnym aparatem mitologicznej erudycji, ale ciężar poruszanych problemów zwiększa się stopniowo — od teatralnej ogólnikowości Udania głosu i osoby móuiąego Ciotka Poniatou'skich... po ważkie obywatelskie tyrady obszernego (478 wersów) poematu Ad quosdam Polonos diffidentes..., w którym obrazowanie fantastyczno-mitologiczne zastapione zostało argumentacją historyczną ${ }^{15}$.

Bolesna pauza biograficzna to także czas jałowy dla twórczości okolicznościowej Kopczyńskiego. Allocutio pontificum... z (prawdopodobnie) 1804 roku jest utworem w stosunkudo poprzednich dokonań dość krótkim (52 wersy) i bardzo zgaszonym. Króla pruskiego trudno tym razem nazwać postacią centralną świata poety — Kopczyński koncentruje się na własnym powołaniu duchownego oraz powierzonych swojej pieczy księży; od polityki odwraca się by tak rzec - ku pobożności praktycznej.

Dopiero twórczość napoleońska stanowi pełnowymiarowy, trzeci etap poetyckiej drogi uczonego gramatyka. Zgodnie z zarysowanymi wcześniej zasadami, Kopczyński jako pijat i jako polski patriota woli kierować swoje wypowiedzi pod adresem nie tyle samego cesarza co blizszego rodzimym realiom księcia warszawskiego Fryderyka Augusta ${ }^{16}$, lub osób zna-

\footnotetext{
${ }^{15}$ Wiersz ten byl jednym z dwócl utworów duby Scjmu Wielkicgo (obok Pourrotu posta Juliana Ursyna Nienu cewicza) omówionych w prasic niemicckojęzyczncj: wedle .Allgemeine Literaturzcitung” (1792 11I, s. 375 zdradzal „wiçcej energii usposobicnia niż wartości poetyckich" (cyt. za: P. Drews, Recepeja beletrystyki polskiej m

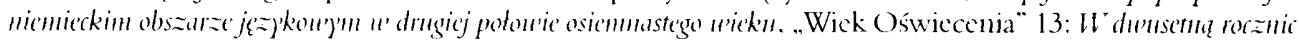
smieri Adama Nartszenticza. Warszawa 1998. s. 204, przyp. 79).

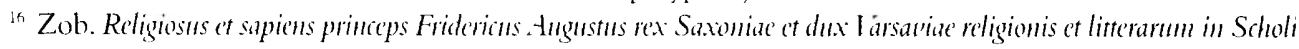
Piis stator. Epigramma [1809)].
} 
czących w hierarchii urzędowej, dziçki którym można wpłynąć na złagodzenie doraźnych uciążliwości wojennych - jak cesarski rezydent w Księstwie Warszawskim ${ }^{17}$, albo też postaci ważkich ze względu na ich ogólnoeuropejski rozgłos - jak narodzony właśnie oficjalny następca tronu'ir.

Ostatni etap aktywności Kopczyńskiego jako poety okolicznościowego - co łączyło go z wieloma innych literatami klasycyzmu „warszawskiego” czy ,postanisławowskiego”przebiegal w blasku (czy też: w cieniu?) postaci cesarza Aleksandra I, ,anioła pokoju” (jak pisał o nim Alojzy Feliński w pierwotnym tekście pieśni „Boże, coś Polskę...”), który zdawal się, podejnuıjąc się imperialnej opieki nad Królestwem Polskim, zaspokajać polskie nadzieje w stopniu wyższym i pewnicj niż Napoleon. Juz podczas Kongresu Wiedeńskiego, w październiku 1814 Kopczyński zwracal się ku przewidywanemu nowemu protektorowi Polaków; przypominal i logicznie argumentowal nie tylko niedawne złudzenia narodowe, związane z postacią cesarza Francuzów, lecz także odwolywal się do tradycji odsieczy wiedeńskiej Jana III Sobieskiego, sytuując obrady kongresu w ramach etycznej powinności zadoścuczynienia za bohaterstwo Polaków, zarówno to niedawne, motywowane pragnieniem odzyskania utraconej ojczyzny, jak i tanto sprzed stu trzydziestu lat ${ }^{1 \%}$. Ostatnie zaś wersy Kopczyńskiego pod adresem cara, składane pod wplywen okoliczności zewnętrznych, przeniknąl jeszcze duch panslawizmu ${ }^{21}$ - były to jednak już dowody zmierzchu sil twórczych ponad osiemdziesięcioletniego starca.

Fakt, że wzmiankę o gramatyce polskiej dedykowanej „Najjaśnicjszemu Cesarzowi i jego Wielkiej Armii wkraczającej do Polski" Kopczyński uznał za stosowne zamieścić jako przypis

\footnotetext{
${ }^{17}$ Zob. pocmat alegoryczny (przez autora mazwany . historycznym") na kanwic zajẹcia budyuku Collegium Nobilimm przez francuski szpital wojskowy, a nastẹpnic czçściowego odzyskania go przez zakon: De larsatiensi

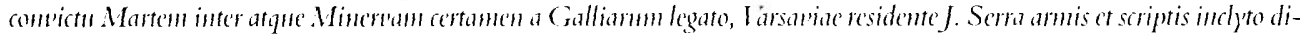
remptum. MDCCC.I III ..., |b. m. dr.]. - Litcracką sylwetkę Serry, autora stylizowanych na rzymska prozę hi-

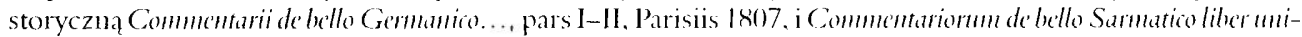
as, Dresdac, [b. r.]. przypomnial ostatnio Marian Plezia - zoh. Zapommiany 'tacinski dsicjopis Vapoleona I, [w:] idem, $Z$ dzicjón, filologii klasycznej " Polsce, Warszawa 1993, s. 128-136: pierwodruk (z dedykacją dla Jerzego Axera): .Przegląd Historyczny” t. 82, 1991 z. 3-4, s. +97-5(1)3.

${ }^{18}$ Zob. Napoleonis Magni primogrenito, nato Romnanorum regi, carme'n sacrum - anonimowy rçkopis Bibliotcki Jagiellońskicj w Krakowie. sygn. 5633 (ze zbiorów Żegoty Paulego). Szczególowe uzasadnicnic atrybucji autorskicj. analiza treści utworn i edycja tekstu lacińskiego zob. I. Wójcicki, „Król rzymski nam się nurodzit". Polacy' "kotyski Napoleona 11. „Napis" seria 4, 1998. s. 173-188 (edycja pocmatu od s. 181).

1"Zob. Kalcudac Octolves MDCCCXIl: Ad Congerssum I indohonensem [b. m. dr.]. Wspólcześnic ukazaly sį̧ w drukach ulotnych tlumaczenia: wierszowanc polskic Józe fa D Donizego Minasowicza i fiancuskic prozą Jana Baudouina de Courtenay.

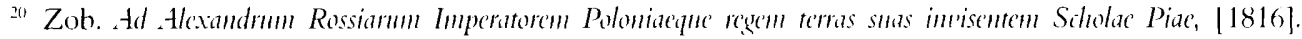
Wspólcześnic ukazalo siç w druku ulotnym thumaczenie francuskic prozą Jana Baudouna de Courtenay. I listoryk i bibliograf zakonu wśród rękopisów pozostawionych przez Kopczyniskiego wymicnia także „niedokończony poemat o zjednoczeniu Slowian" - zob. Sz. Bielski. Catulogurs librormm bibliothecae Collegii Regii I iarsaniensis Clcriconm Regularium Scholarmm Piarum renonatus, Varsaviac 1822, s. 497 (poz. 12): . L'mio Slatorum, pocma non tominatum, arkuszy kilka”.
} 
do swego nazwiska ${ }^{21}$ już na karcie tytulowej De I'arsaniensi convictu..., świadczy nie tyle o jego poczuciu wlasnej wartości jako autora, lecz o wadze, jaką pijar przykładał do propagowania wiedzy o walorach kultury polskiej w środowisku międzynarodowej elity intelektualnej a taką z pewnością byli czytelnicy lacińskiego poematu o sporze Marsa i Minerwy, rozstrzygniętym dzięki salomonowej interwencji francuskiego rezydenta ${ }^{22}$.

W tym miejscu można więc przedstawić ideę i niektóre szczegóły wykonania Essai de grammaire polonaise..., tego jakże cennego dla autora, a dziś prawie nieznanego dzieła.

W zakres działań perswazyjnych Kopczyńskiego wchodzi juz rama tytułowa pierwszego wstępu. Napoleon, „Empereur des Français et Roi d'Italie”, nazwany tu został zwyczajowo Wielkim, lecz dalsze określenia mają emocjonahne zabarwienie roden z sarmackiej retoryki, silniejsze od stosowanych w cesarskiej kancelarii. Nie bacząc na wszelkie wahania ostrożnej oficjalnej propagandy:

Czy zostanie ponownie ustanowiony tron Polski, i czy ten wielki naród powróci do istnienia i odzyska niepodległość? Czy powstanie do życia z głębi swego grobu? Sam Bóg, w którego rękach spoczywają losy wydarzeń, rozstrzygnie ten wielki problem polityczny ${ }^{23}$

- Napoleon obdarzony został mianem „Toujours Anguste, Toujors Lainqueur, Restaurateur et Protecterur de la Pologne".

Oba wstępy: dedykacja cesarzowi (jako między innymi „Zbawcy i Opiekunowi Polski”) i przedmowa (skierowana po prostu „do Francuzów” - Aux Français) uświadamiają od razu, jak autor dba o wysoki poziom stylistyczny i rzetelność wywodu. Nie tylko odezwa do użytkowników dziela ma charakter użytkowy, lecz nawet adresowany do Napoleona wstęp, daleki od jalowych pochlebstw, jest w zasadzie miniaturowym treściwym esejem o naturze narodów, uwidaczniającej się w ich językach; Kopczyński powołuje się tu na zdanie Francisa Bacona. Następnic ukazuje cesarzowi możliwość dowiedzenia się z kart prezentowanej książki, jaka jest „dusza, uczucia, postrzeżenia i myśli zarówno dawnego Sarmaty, jak i dzisiejszego Polaka"-2t. Osiem stuleci - powiada autor — ksztaltowało naród rolników i rycerzy, wyposażony we wszystkie cnoty „towarzyskie” (społeczne). Na naszą korzyść przemawiają także niedawne wydarzenia polityczne: Sejm Wielki, Konstytucja 3 Maja, „rewolucja roku 1794”. i „wszysthie tyloletnie wysitki podejnowane w obronie wolności i w celu zrzucenia niewol-

2! -. Antor Grammaticue Polonae ad nsum Gallormu dedicatae Serenissimo Imperatori émsque magno exercitmi intranti Polonian".

22 Zajęcie gmachu Colleginm Nobilimm na lazaret przyspieszylo decyzję władz zakonnych o przeniesieniu cale go zakladu naukowego na stałe do letnicj rezydencji pijarskicj na Zoliborzu. - Jako marginalny literacki ślas lokalowych klopotów zakonu można wskazać powtarzanie siç motywu „kwaterunku” w imieninowych wier szach Marcina Molskicgo. adresowanych w latach 181+-1816 do prowincjala i rektora kolegium warszawskie go Szczcpana Sawickicgo (zob. M. Molski. Pisma..., seria 2, wyd. W. Radliński, Warszawa 1865, s. 310-318).

23 Napoleon Bonaparte. Mony i rozkazy, op. cit. (36. biuletyn Wielkiej Armii z 1 grudnia 1806 roku).

${ }^{24}$ Wszystkic cytaty ze wstẹpów do Essini.. W moim przekladzic - J. W. - W dalszych przytoczeniach pomi jam równolegla do przykladów polskich egzenuplifikację trancuską. 
niczego jarzma”. Także język polski należy do , majlogiczniejszych, najwyrazistszych i najbardziej harmonijnych w Europie"; jego dokładność, jasność i bogactwo odcieni pozwala wyrażać nawet najsubtelniejsze myśli. Zatem mówiący nim naród ma swoje miejsce wśród innych, i godzien jest taskawej opicki cesarza.

Przedmowa do Francuzów nie pozostawia też wątpliwości co do nastawienia autora. Opracowanie gramatyki polskiej jest w jej świetle tylko aktem wdzięczności za ,największą przysługę, jaką ludzie oddać mogą sobie nawzajem": przywrócenie praw, które wydarły nam „zdrada, podstęp i tyrania”. W późniejszym czasie - przewidıje Kopczyniski — za tymi skromnymi początkami pójdą opracowania szersze, które umożliwią przybyszom nie tylko mówienie po polsku, lecz i zapoznanie się z polską literaturą, a jej walory docenią może francuscy uczeni. W zakończeniu autor przypomina, ze czytelnicy nie znajdą tego wyszukania stylu, do jakiego przywykli, bowiem „więcej uciekat się do swej gorliwości niz zdolności”.

W zasadach pisowni Kopczyński podkreśla prostotę wymawiania tego, co się pisze (z wyjątkiem „ch”), nawiązując do pomysłów uproszczenia pisowni francuskiej z czasów Rewolıcji; niemniej w dalszych rozdziałach pilnie przestrzega, dość przecież skomplikowanego, kreskowania samoglosek i spółgłosek wedle swoich stałych regul, znanych z innych jego podręczników.

Ciekawie autor tłumaczy bogactwo zarówno samogłosek, jak i spółgłosek polskich: pierwsze są znamieniem i wytworem narodu lagodnego i gościmnego, drugie - tegoż samego narodu, lecz tym razem wojowniczego i groźnego dla wrogów.

Nie warto w tym miejscu przytaczać formułowanych na kartach Essai... zasad grannatycznych, ponieważ tym, co stanowi o perswazyjno-etycznym wydźwięku książki, jest przede wszystkim charakter użytych przykladów. Mówiąc krótko: nawet psalm LXVIII w thumaczeniu Jana Kochanowskiego, ilustrujący części mowy (s. 26-27), dobrany zostal pod kątem tematyki imperialnej i walki w słusznej sprawie:

O, który światem władasz i królujesz wiecznie,

Powstaní, Panie, a muszą tyl podać koniecznic

Nieprzyjaciele Twoi; wszyscy, którzy śmicja

Upór wieść przeciw tobie, do czysta zniszczeją.

Tak zniszczeja, jako dym na powietrzı ginie,

Albo jako topniący wosk od ognia plynic.

Dlatego oprócz przykładowego „wykrzyku”: „Alıa! znan cię, piçkny ptaszku!” („He! je te connais, bel oiseau!") częściej pojawiać się będą sformulowania z rejestru: „Daj go Bogu, co za zwycięstwo!” („Parbleu! quelle victoire!”, s. 31). Odnnianę̧ rzeczowników żeńskich ukażą przykłady: „Polska”, „wiezza”, „pani” (s. 59-60); nijakich: „książę”, .słoníce”, „wojsko” (s. 63-64); przymiotników męskich: „sam król”, „sam tron” (s. 67). Okazją wpływu na moralne usposobienie czytelników nogą być nawet enklityki: „Ten to zbawca naszej ojczyzny? - Taż to ręka dobroczynna? (...) Tenże to uspokoiciel świata?" (s. 74-75). Nic zatem dziwnego, ze przykłady form słowa positkowego „być” to zwroty: „Mialem być u Cesarza. - Miałem go prosić. - 
Mam to zrobić jutro. - Ten, który ma się stać królem polskim, ma być koronowany w Krakowie" (s. 116), a formy mianownika (s. 146-147) ilustrowane są następującymi pytaniami i odpowiedziami:

Kto tam jest? - Ja żołnierz.

Kto mię tam czeka? - Matka Ojczyzna.

Kto tam płacze? - Dzieciątko, sierota.

Co pali? - Ogień. - Co gasi? - Woda.

Który to żohierz na warcie? - Polak.

Która to matka Ojczyzna? - Polska.

Które to dziecię wychowujesz? - Podrzucone.

Co za zwycięstwo odniesione? - Pod Jeną.

Podobnie z wzorów przypadka szóstego („narzędnika lub narzędziowego”, s. 151) francuski czytelnik dowiaduje się także (s. 150):

Bogiem a prawdą, wszystko się dobrze dzieje.

Sarmaci orzą ziemię pługienn.

Rysuja granice, czym? szablą; jaką? zwycięską.

Karmią się gościnnością.

Płacą w dwójnasób wdzięcznością.

Według tego samego klucza ulożony zostal wykaz przyimków (s. 83-84), co — zwłaszcza po przepisaniu tekstu ciąglego w wersach - nadaje mu pozór nieledwie podniosłej prozy patriotycznej o zacięciu psalmodycznym:

Blisko dwakroć sto tysięcy Francuzów

dla równowagi europejskiej

do Polski uciemiężonej

lla poratowanie jej słabości

nad wszelkie spodziewanie, nie stojących, tylko

o honor i sławe, przyszedlszy

of oceanu zachodniego,

pod opieką nicbios,

prze miłość ludzkości, oświadczając

przed niebem i przed ziemią, że ich sprawa była słuszną, i lecąc nieustraszenie przez góry, lasy i rzeki,

przy powadze i szczęściu Wielkiego Napoleona,

rozbiwszy calą potęgę pruską,

s całą wojskową sila

u' zimie dżdzystej

ll'eszli w Podlasie,

u'ybili część Moskalów 
z odwagą niestychaną; resztę wyrzucili

za granice,

a za powrotem tryunfalnym ogłosili Polskę wolną.

Po takim tour de force wystarczy przytoczyć początek i koniec wykizu przyinków (s. 156-159), by dać pojęcie tak o nim, jak i o innych objaśnienniach zjawisk grannatycznych:

Lećmy na plac utarczki,

odniesiemy z niego wawrzyny,

pójdźcie z namni, mężni Polacy,

idzie tu o waszę ojczyzuç.

Moskale z bojaźni uciekli do lasa (...)

piechota wpada ${ }^{\prime}$ niclad,

wołają na świętego Mikołuszkę (ils crient à St. Nicolas),

ale dobry Bóg jest z nami,

rzucają siç $u$ ' krzaki,

spod ziemi ich dobędziemy,

sponad księzyca spadna.

przed Napoleonem idzie śmiałość i szczęścic,

14 prawej Francuzi, na lewej Polacy,

zwycięstwo i tryumf idą za Nim.

Trudno wobec tego przypuszczać, aby przykłady zdań rozkazıjących (s. 171) mogly brzmieć inaczej niz: „Niech Polska będzie wolną. - Niech Polacy będą niepodległymi. Niechaj trzej łupieżcy wracają, co cudzego. - Niech każdy swoje dzierży".

Tomik zamykają trzy Rozmon'y potoczme (s. XII-XIX). O ile Nauriedziny' nie różnią się zbytnio od typowych przykładów uprzejmej konwersacji, o tyle już Śniadanie i obiad kończy się kwestią Francuza trudną do funkcjonalnego zreprodukowania w żywej mowie:

Ten barszcz jest rozkoszny. Sztuka mięsa przedziwna, pieczenia uzarska wyborna. Napój wasz zwany malinnikiem i wiśniakiem podobny nektarowi. Co za śliczne, co za słodkie owoce wydane w pótnocnej krainie!

Natomiast najobszerniejsza „rozmowa” trzecia, Kraj i jego jezzłk, składa się z pięciu zaledwie kwestii, z których pierwsza Francuza to rozbudowana wypowiedź na temat "Co Waćpan rozumiesz o Polsce?”, a dwa razy dluzsza Polaka to w zasadzie wykład ,jeografii i statystyki krajowej". Francuz wyznaje:

(...) Ale już wychodzę z dawnego i pospolitego przesądu gardzić i nazywać grubiańskim, co tylko jest cudzoziemskim. Widzę tu dobre obyczaje, szczerość i grzeczność, wrodzoną gościnność, przywiązanie do Francji przez podobność charakteru i przez wdzięczność. (...)

Polak zaś konstatıje między innymi: 
(...) Polska do dawnego stanu przywrócona będzie Francji bardzo pożyteczna. Przez polożenie swoje stanie się mocnym wałem dla sprzymierzonej Europy, a przez urodzaje swoje powiększy handel przedaży i kupna. (...)

Co za morze do czerpania w księgach waszego języka! Pałam chęcią nauczenia się go z gruntu (...) -

domaga się Francuz w ostatniej części rozmówek z Essai...

Jak zaś naprawdę - o ile wierzyć ówczesnym przekazom - wyglądala kwestia orientacji cudzoziemców w zawiłościach języka polskiego?

Zacząć można od przypomnienia, że jednym ze zjawisk, obserwowanych przez oświeconych przybyszy na ziemie polskie na przestrzeni kilkudziesięciu lat, a ocenianym zwykle jako kolejny paradoks narodu jednocześnie nędznego i dumnego, była możliwość porozumienia się w języku lacińskim nawet z najniższymi kręgani społeczeństwa. Tak oto Anglik William Coxe (autor niezwykle popularnej w Europie schyłku XVIII wieku książi o naszym kraju) rzucone podczas rozmowy spostrzeżenie króla Stanislawa Augusta o powszechnej wśród Polaków znajomości łaciny opatruje przypisem:

Mialem niejednokrotnie sposobność zauważyć ogólną umiejętność wladania tym językiem w Polsce. Kiedy zwiedzałem wiçzienia, rozmawiałem po lacinie ze zwyklym zołnierzem stojącym na warcie u wejścia; mówił tym językiem bardzo biegle ${ }^{25}$.

Jeszcze po piętnastu latach wtórują mu: Ślązak Johann Joseph Kausch (przy okazji cierpkich uwag pod adresem kleru katolickiego, niedbatego w staraniach na rzecz społeczeństwa):

(...) ciagle jeszcze do rzadkości należy na polskiej wsi porządnie prowadzona, chociaż jeszcze niedoskonała szkoła. Mimo to częściej tu niż w innych krajach cywilizowanych spotkać można służącego znającego choć pobieżnie lacinę; spotkałem wlaśnie takiego woźniç $e^{26}-$

oraz dwaj arystokraci francuscy, skądiną̧d dostrzegający chłodnym okiem przerażającą bied większości kraju:

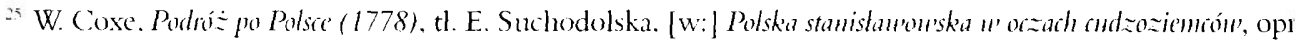
W. Zawadzki, t. 1. Warszawa 1963, s. 65\%.

26 J. J. Kausch. Wizcrumek narodu polskiego |1793]. tl. W. Zawadzki, [w:] ibidem. t. 2, s. 328: autor objaśnia tak stan rzeczy w następuymu zdaniu: .,Pochodzi to stąd, ż bardzo czẹsto przyjmuje siç do domów szlacheckicl jednego lub kilku modych chlopców, aby uczyli ushugiwać, a równocześnic, aby rywalizowali w nauce z mo dymi paniczami". 
Język łaciński jest często używany w Polsce, i to w różnych warstwach ludności. Zdarzało nam się napotkać żolnierzy wcale nieźle wladających łaciną. Pocztmistrze, gdy podróżny nie odpowiada na pierwsze pytanie w języku polskim, uciekają się do laciny ${ }^{27}$.

W dobie napoleońskiej funkcjonalność laciny okazywała się jednak złıdıa, a porozumienie już niemożliwe. Kazimierz Władysław Wójcicki z tradycji rodzimnej przytacza opowieść o daremnym zachıycie .zbawcami” francuskini, którą objawiał burmistrz Pragi Jezierski. Przeprawiwszy się przez Wistę, wygłosił on do wartownika przed Zamkiem ..przemowę po lacinie, czego żohnierz sluchał z podziwem i uśmiechem", a liści po kilku dniach Francuzi, dotarłszy już na prawy brzeg Wisły, podczas furażu zerwali go nocą z pościeli i zmusili, by bez przyodziewku natychmiast prowadzil ich i dostarczyl siana i owsa dla koni:

Kiedy go mój dziad, spotkawszy, zapytal z uśmiechem: „A co nasi zbawcy?”„Niech ich wszyscy diabli porwa!!" - zawolal Jezierski i opowiedzial swoje zdarzenie $e^{28}$.

Tyle co do łaciny, długo postrzeganej jako skuteczne narzędzie porozumienia. Jednak stosunek większości cudzoziemców do samej polszczyzny oddają chyba dość wiernie słowa znanego jako „Inflantczyk” Friedricha Schulza, nie pozostawiającego ewentualnym adeptom zbyt wiele nadziei:

Polacy mówią bardzo szybko i umieją dwie lub trzy spólgłoski tak prędko po sobie wsunąć, iz jednym tchem spadają na samogłoskę i w jeden się ton spływają. Ich dlugie wyrazy o połowę się skracają, a wyraz, na papierze wydający się bez końca długim, prędzej się wymawia niż niemiecki dwı- lub trzygłoskowy. Potrzebnej ku temu zwinności organów glosowych można tylko nabyć wprawą od dzieciństwa zyskaną; po latach pięćdziesięciu pobytu w Polsce cudzoziemca zawsze wymowa zdradzi, że się w tym kraju nie urodził. (...) Francuzom łatwiej przychodzi wyuczyć się dobrze po polsku, zdradzają się tylko nosowymi tony swymi. Wlosi o wiele trudniej uczą się po polsku, bo ich język, jak niemiecki, ma chód powolniejszy. Anglika po polsku mówiącego nie styszalem, ale się domyślam, ze mu jego język, plączący się ciągle koło zębów, i dziecinna wymowa do polskiej mowy nie są pomocne. W ogólności należy przypuszczać, że naród, którego mowa jest najszybszą, nạlepiej siç po polsku wyuczyć potrafi²".

\footnotetext{
${ }^{27}$ F. de Piles, B. de Kerdu, Podrís du'ćch Francuzóm, t1. W. Zawadzki. [w:] ibidem, s. 727.

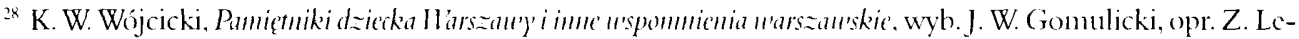
winówna, wst. M. Grabowska, t. 1. Warszawa 1974, s. 53-54. - Odmienny, pozytywny, choć zarazem odosobniony przyklad funkcjonalności laciny w kontaktach Polaków z dworem cesarskin podczas kampanii

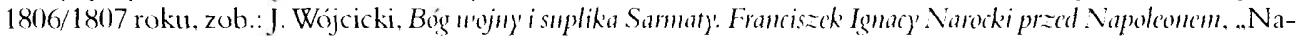
pis", seria 5, 1999, s. 153-167.

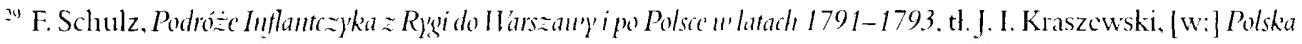
stanistawou'ska..., op. cit., t. 2, s. 613 .
} 
W charakterze komentarza do lingwistyczno-pośredniczących starań Kopczyńskiego warto też wspomnieć, że akurat w związku z militarnym wysitkiem wojsk napoleońskich na ziemiach polskich, w wypowiedziach przybyszów wyraziście ujawnił się krzywdzący stereotyp niskiego poziomu umysłowości Polaków i prymitywnego poziomu ich języka. Interesujący wydaje się przy tym nie tyle początek (zapewne tylko zwięzły, dowcipny i w sumie neutralny opis pewnego zjawiska), ile stosunkowo krótka, lecz zadziwiająco eféktowna wędrówka tego motywu, z każdym przywołaniem otaczającego się nowymi znaczeniami, na kształt śniegowej kuli na zboczu.

Najwcześniej ogłoszonym źródłem owego kuriozalnego opisu polszczyzny, wedle doświadczenia Francuzów złożonej z czterech zaledwie wyrazów, są ogłoszone w roku 1823 pamiętniki generała Jeana Rappa, który jednocześnie przytacza anegdotę związaną z postacią samego cesarza - dość oryginalnice, tak że „nikt się już więcej niczego nie domagal”, oddalającego skarge na kłopoty aprowizacyjne armii, spowodowane błotnistymi drogami:

Quatre mots constituaient, pour e'ux, tout l'idiome polonais: Kleba? niema; vota? sara; du pain? il "n'y' en a pas; de l'enu? on w'a e'n apporter. C'était lì toute la Pologne.

Napoléon traversait un jour une colonne d'infanterie aux environs de Nasielsk, ou la troupe ćprounait de grandes privations à cause des boues qui empêchaient les arrivages. „Papa, kleba?", Ini cria un soldat. „Niema”, répondit l'empereur. Tonte la colonne partit d'un éclat de rire; personne ne' demanda plus rien"

Jeśli wierzyć wspommieniom oficera sztabowego marszałka Lannesa, Jakuba Kierzkowskiego, ta .rozmowa” z wojskien, zręcznie sterowana socjotechnicznie przez cesarza, toczyla się w większym gronie, w dynamicznej scenerii bliżej niesprecyzowanego czasowo przeglądu 5. korpusu, gdy żohnierze (już nie tylko „un soldat”) krzyczeli w marszu: „Papa, chleba!”:

Nie rozumiał Napoleon, co to jest „chleba”, dopiero przywołali kapitana Falkowskiego, aby go po polsku nauczyl, jak odpowiedzieć: „nie masz chleba”. Nauczyl się też prędko tego Napoleon, a gdy wojsko maszerowato koło niego (...), on się obraca z uśmiechem i odpowiada im po polsku:

- Nie masz chleba!

Wówczas oczarowani żohnierze krzyczeli:

- Vivel'cmperenr!

3" I. Rapp. Mémoires..., Paris 1823, s. 119-120 (rozdz. XVI). Za Rappem anegdotę rychlo upowszechnil (bez lokalizacji zdarzenia) miçdzy innymi Antoinc Vincent Arnaute w bogato ilustrowanym albumie I" ie politique e milituire de Napolkon. t. 2. Paris 1826, s. 64. Bez powolania się na źródlo (a miejscem spotkania czyniąc tym ra-

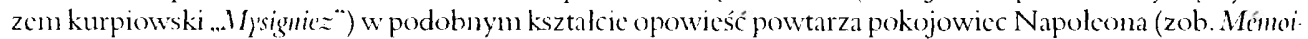
res de Comstum, premier ralet de chambre de l'Empertur..., t. 3. Stuttgart 1830, s. 30+305). Szczególów nie zawier: tcż wzmianka polskicgo pamiçtnikarza: ..I tak ma przykład przypominam sobie, że wyrażenia: kleba nie ma woda zara. były na ustach każdego Francuza, a nawet samego cesarza" (J. Szymanowski, Pamiq̨niki. Lwóv 1898, cyt. za: Dat nam przjktad Bonaparte. Wipommienia i relacje zotmicrzy polskich 1796-1815, wyb., koment i przyp. R. Bielecki, opr. tekstów A. T. Tyszka. t. 1. Kraków 1984, s. 150, 159 - tu objaśnienic autora).

${ }^{31}$ J. Kicrzkowski. Pamiętmiki. Warszawa 19(1)3, cyt. za: Dat man przjkfad Bomaparte..., op. cit., t. 1, s. 153. 
Wolno sądzić, że owo „oczarowanie” dotyczylo tylko niespodzianki językowej, sprawionej przez cesarza, chcącego podchwyceniem doraźnego odezwania i zaskakującym podjęciem stylu kontaktu z podwładnymi rozładować napięcie podskómie nurtujące żołnicrzy, a tym razem zamanifestowane zaledwie pólżartem - jeśli rzeczywiście w głos odzywało się wielu, nie jeden tylko gwardzista. Ale z kolei popularny biograf (a wlaściwiej rzec: hagiograf) Napoleona z lat czterdziestych pod haslem Stara gu'ardia chae jeść rozbudowal skrótową anegdotę aż do rozmiarów dhuższego i statyczniejszego dialogu (bez lokalizowania go geograficznie; jakoby po bitwie pod Iławą Pruską, więc już na początku lutego 1807 roku), gdzie entuzjazm wojska (co prawda, lekko surrealistyczny), początkowo zbuntowanego, idzie o lepsze z rysami doskonałości cesarza, który nie musi juz u nikogo zasięgać porad językowych:

- (...) No i co to ma wszystko znaczyć? Dlaczego stançliście pod bronią bez mego rozkazu?

— Papa, „kleba”! - jedıym głosem wrzasnęli grenadierzy. Cesarz, rozumiejąc stowo „chleb”, odpowiedział tak, że wszyscy dobrze słyszeli.

- El bien, nie ma!

— Niech żyje cesarz! — odkrzyknęła Gwardia z takim zadowoleniem, jak gdyby juz ją nakarmiono do syta ${ }^{32}$.

Do stereotypów i uprzedzeń kulturowych, a zarazem do zagadnień językowych, odnosi się też zanotowany w ówczesnym źródle nieco późniejszy epizod kontaktów polsko-francuskich. Podczas baluw Teatrze Narodowym 5 listopada 1807 roku, zorganizowanego przez generalicję francuską w rewaużu za ucztę wydaną na cześć Francuzów przez oficerów polskich, przedstawiono także komedię w języku francuskim. Wspólczesna antologia literacka przytacza z niej trzy strofy (po polsku, zapewne w przekładzie na uzytek owej antologii). Nie jest jednak jasne, czy inicjatywa zaprezentowania takiego pojednawczego występu wyszła od cudzoziemców („Strofy te śpiewa oficer na scenę wchodzący, świeżo niby z Francji przybyly”głosi nagłówek utworu), czy téz — wolno podejrzewać raczej taką okoliczność — okazję tę pośpieszyli wykorzystać autorzy polscy:

Mniemałem, ze antypody

Ujrzę ponniędzy Polaki,

Lecz co widzę! nasze mody,

Ten sam dowcip, ubiór taki.

Obyczaje grzeczne, żywe, Język, co ich do nas zbliża,

${ }^{32}$ E. M. de Saint-Hilaire, Historia Napoleoma, tl. L. Rogalski. przedm. A. Nicuważny, Gdańsk 2004, s. 203 (rozdz. XVI). Pierwodruk przekładı polskiego: Warszawa 184t: doslowny cytat (bez wskazania źródla) w swoim zbiorze ...negdot i historyjck" napolconískich przytacza Stanistaw Wasylewski-zob. idem, Zcru'ana kokarda, Kraków 1965 (pierwodruki obu czçści tomu: 1923, 1927), s. 137-138. 
I damy tak urodziwe,

Jak gdyby w pośrzód Paryża. (...)

Czy rzeczywiście, w świetle choćby powyższych cytatów, „językiem, co ich do nas zbliza” mógł być wówczas polski? „Gramatyka dla zbawców”, nie tylko z przyczyn zewnętrznych, polityczno-historycznych, nie miała chyba szans stać się czymś więcej niż tylko szlachetnym złudzeniem wybitnego nanczyciela narodu. Przenikająca karty Essai de grammaire polonaise... pour les Franı̧ais perswazyjność i etyczne waloryzowanie przykladów gramatycznych, a zwłaszcza zupełnie niepraktycznych rozmówek, i tak zaciążyły nad przydatnością tomu. Niemniej książka Kopczyńskiego — w formie praktycznego poradnika językowego pragnąca uświadomić zdobywcom świata ich powimności moralne w stosunku do narodu poniżonego politycznie, lecz bogatego kulturowo, sprawnego intelektualnie, duchowo niezawisłego, w samej strukturze mowy przechowującego umiłowanie niepodległości ${ }^{3+}$, którą mu nie tak dawno wydarto - wydaje się zjawiskiem wyjątkowyın w dziejach kontaktów międzykulturowych calej epoki napoleońskicj. Jcj autor podjąl trud zaprzeczenia kłamliwym stereotypom i uświadomienia czytelnikom - zarówno Cesarzowi, jak i każdemu szeregowcowi w szyku, w obozie czy na kwaterze - ze przemarsz Wielkiej Armii przez ziemie Polski to nie tylko mozolna pogoń glodnych i zziębniętych, skorych do buntu zohnierzy za kryjącym się w puszcze nieprzyjacielem, lecz że przede wszystkim tędy wiedzie szlak, którym wędruje wolność choćby nawet byly to grząskie bezdroża, jakże niesprawiedliwie obrzucane pogardliwymi pomrukami wiarusów:

Quoi! les Polonais osent appeler cela me patrie!... 35

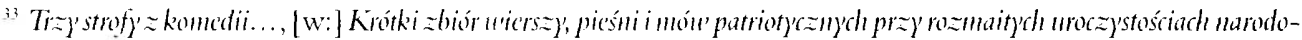

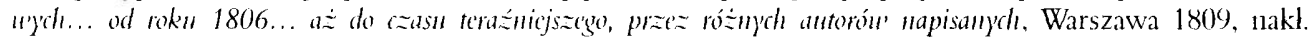
M. Chmiclewskicgo, s. 52-53.

it "Les Polomais n'aiment pus l'esclarage, même dans le discours" (początek wyjaśnienia swobody szyku zdań polskich - O. Kopczyński, Essai..., s. 134).

${ }_{35}^{3}$ [M.] de Marbot, Mémoires.... t. 1, Paris [b. r.]. s. 316 (rozdz. XXXI). - Mino calego tadunku cmocji ter efektowny aforyzm sprawia wrazenic obicgowego zwrotu, niczwiązanego genetycznie z kampanią polską Wprawdzie Józef Szymanowski (op. cit., s. 150) odnosi slowa te do reakcji Francuzów na warunki terenow Mazowsza w okolicach Golymina i Pultuska, w grudniu 1806 roku: .....maszcrując w blocic po kolana, wszys cy prawic wohali: "Ach, co za przeklę̧te bagno, i oni nazywają to ojczyzną!»". Jednak de Saint-Hilaire (op. cit. rozdz. XIII. s. 171) przytacza je jako refleksję grenadiera francuskicgo, stapającego po zanicdbanych ulicacl Wicdnia podczas uroczystego wkroczenia do pokonancj stolicy Austrii 13 listopada 1805 roku: „- I oni wskazal przy tym na Wiedeńczyków. przypatrujących się cickawic żonierzom - nazywają to ojczyzną, a prze ciez to tylko bloto". 